\title{
Kiterjedt, demarkált pancreas necrosis sebészi kezelése transgastricus necrectomiával
}

\section{Open transgastric necrosectomy for extended walled-off pancreas necrosis}

\author{
BALOG KLAUDIA ${ }^{1, @}$, CSISZKÓ AdRIENN²${ }^{2}$, KRASNYÁNSZKY NÓRA ${ }^{3}$, FARKAS MÁTÉ $^{1}$, \\ BERHÉS MARIANN ${ }^{4}$, LÁSZLÓ ISTVÁN ${ }^{4}$, PALATKA KÁROLY ${ }^{5}$, DAMJANOVICH LÁSZLÓ ${ }^{1}$, \\ SÁPY PÉTER ${ }^{1}$, SZENTKERESZTY ZSOLT ${ }^{1}$ \\ ${ }^{1}$ Debreceni Egyetem Klinikai Központ, Sebészeti Intézet, Debrecen \\ ${ }^{2}$ Semmelweis Egyetem, I. sz. Sebészeti Klinika, Budapest \\ ${ }^{3}$ Debreceni Egyetem, Általános Orvosi Kar, Debrecen \\ ${ }^{4}$ Debreceni Egyetem Klinikai Központ, Aneszteziológiai és Intenzív Terápiás Tanszék, Debrecen \\ ${ }^{5}$ Debreceni Egyetem Klinikai Központ, Belgyógyászati Klinika, B Épület, Debrecen
}

\begin{abstract}
Bevezetés: Akut pancreatitis miatti necrectomiát ideálisan a betegség kezdetétől számított 4-6. héten javasolt elvégezni, amikor az ún. demarkált necrosis (walled-off pancreatic necrosis -WOPN) már kialakult. A szerzők ismertetik a kiterjedt WOPN miatt végzett sebészi transgastricus necrectomiák során nyert tapasztalataikat. Betegek és módszer: Kiterjedt WOPN miatt 2012. január 1-től 2017. december 31-ig terjedő időszakban 17 (12 férfi, 5 nő, átlag életkor 64,00 $\pm 15,14$ év) betegnél végeztek sebészi transgastricus necrectomiát. Valamennyi betegnél a mütétet megelőzően konzervatív és szemikonzervatív kezelés történt átlagosan $61,00 \pm 33,47$ napig. A WOPN mérete átlagosan $14,00 \pm 5,23 \mathrm{~cm}$ volt és valamennyi esetben a retrocolicus, retroduodenalis terekbe is beterjedt. A necrosis minden esetben bakteriálisan kontaminált volt. Eredmények: A mütétekkel kapcsolatos szövődmény nem volt. Az ápolási napok száma a mütétet követően 10,00 \pm 3,08 nap volt. A mortalitás 5,9\% volt. Késői mütét vagy egyéb beavatkozás pseudocystaképződés, vagy pancreas fistula miatt nem volt. Két betegnél a WOPN és a gyomor közötti anastomosis-endoszkópos tágítása és öblítése történt lázas állapot miatt. Frissen kialakult diabetest nem, a meglévő súlyosbodását 6,3\%-ban észleltük. Következtetés: A kiterjedt, fertőzött demarkált necrosis kezelésében a sebészi transgastricus necrectomia jó eredménnyel alkalmazható. A mütét előnye, hogy a necrectomia után nem alakulhat ki külső pancreas sipoly és pseudocysta.
\end{abstract}

Kulcsszavak: demarkált necrosis, transgastricus necrectomia

Aims: In severe acute pancreatitis the timing of necrosectomy is ideally should be postponed 4-6 weeks after the onset of the disease when the walled-of pancreatic necrosis (WOPN) has developed. The authors present their experience with open transgastric necrosectomy for extended WOPN. Patients and methods: The authors performed 17 (12 male, 5 female with a mean age of $61.6 \pm 15.1$ years) open transgastric necrosectomies for extended WOPN in a period of 1, January 2012 and 31, December 2017. Before the operations conservative and semiconservative therapy was used for an average of $74.6 \pm 83.1$ days. The mean size of the WOPNs was $13.8 \pm 5.2 \mathrm{~cm}$ with localisation of the retrocolic and retroduodenal regions. All necroses were septic. Results: Complications related to the operation were not observed. The mean time of hospitalization after the surgery was $11.6 \pm 12.8$ days. The mortality rate was $5.9 \%$. Late operation or other interventions for pseudocyst or pancreas fistula formation was not performed. Two patients needed endoscopic dilatation with lavage in the early postoperative period because of fever. New diabetes mellitus was not observed but worsening of previously existed diabetes developed in $6.3 \%$ of the cases. Conclusions: The open transgastric necrosectomy is safe and effective for extended WOPN. The advantage of this type of necrosectomy is the prevention of pancreatic pseudocyst and fistula formation.

Keywords: walled-off pancreas necrosis, open transgastric necrosectomy

Beérkezett: 2018. október 10.; elfogadva: 2019. február 13.

@Levelezési cím/Corr. address: Dr. Balog Klaudia, Debreceni Egyetem, Klinikai Központ, Sebészeti Intézet, 4032 Debrecen, Móricz Zs. krt. 22.; Tel.: 0670/411-8350; Email: klaudia.balog@live.com 
Rövidítések: BMI - Body Mass Index, CT - Computer Tomográfia, NE - Nemzetközi Egység, WOPN - Walled-off Pancreas Necrosis

\section{Bevezetés}

A súlyos akut pancreatitisben, amennyiben sebészi kezelés szükséges, annak ideális időpontja a betegség kezdetétől számított 4-6. hét, amikor már kialakult az ún. demarkált necrosis. A demarkált necrosis (walled-off pancreatic necrosis - WOPN) egy heges fallal körülvett elváltozás, mely elhalt pancreas- és peripancreaticusszöveteket, hasnyálat és/vagy gennyet tartalmaz. Ebben a stádiumban a szeptikus góc már lokalizált, a szöveti elhalás demarkációja már befejeződött, így ideális viszonyokat teremt a necrectomiához. ${ }^{1-18}$

A fertőzött WOPN intervenciós kezelése akkor javasolt, ha a konzervatív és intervenciós radiológiai kezelés eredménytelen és/vagy szervi elégtelenség alakul ki az elváltozás miatt. Néha a demarkált necrosis mérete, valamint az általa okozott tartós panaszok miatt infekció nélküli esetekben is indokolt lehet a mütét. 1,3,5,6,8,10-14,16-19 Kisebb WOPN esetén a direkt endoszkópos transgastricus necrectomia és egyéb minimálisan invazív kezelés a választandó módszer. ${ }^{3,4,11-16,18-20}$ Nagyobb kiterjedt necrosisok esetén a sebészi kezelés indokolt. Számos minimál invazív kezelés mellett a nyitott necrectomia napjainkban sem nélkülözhető eljárás. A sebészi necrectomiák két alapvető típusa ismeretes. A hagyományos necrectomia esetén az elhalt szövetek eltávolítása után a bursaomentalist nyitva kezelik, vagy zárt öblítést alkalmaznak. ${ }^{3,4,6,8,12,14,19}$ A másik lehetőség a transgastricus necrectomia, mely tulajdonképpen a Jurasz-mütét megfelelöje, melyet a necroticus szövetek eltávolításával egészítenek ki. A mütét előnye, hogy a beavatkozás jellegénél fogva nem alakulhat ki pancreas sipoly és áltömlö. 1,2,5-8,10-12,14-16

A szerzők - Magyarországon először - ismertetik a WOPN miatti transgastricus necrectomiával elért eredményeiket.

\section{Betegek és módszer}

A DEKK Sebészeti Intézetében 2012. január 1-től 2017. december 31-ig 17 betegnél végeztek transgastricus necrectomiát. A betegek közül 12 férfi és 5 nő volt. Átlagéletkoruk $64,00 \pm 15,14$ év volt. A betegség vélhető kiváltó oka 8 $(47,1 \%)$ esetben epekő betegség, $6(35,3 \%)$ esetben étel- és alkoholabúzus, $4(23,5 \%)$ esetben ismeretlen volt.

Valamennyi beteg hasnyálmirigy-gyulladása a módosított Atlanta Klasszifikációnak megfelelően súlyos volt. A kezelési elveknek megfelelően a betegeknél az ún. „stepup” kezelést alkalmaztuk. Intenzív osztályos ellátás részeként a kialakult szervi elégtelenség kezelése mellett a betegnél korai nasojejunalis szondatáplálást és szeptikus tünetek esetén tapasztalaton alapuló vagy célzott antibiotikum- kezelést indítottunk. Rutinszerüen antibiotikumprofilaxist nem alkalmaztunk. Nagyobb kiterjedésü steril és fertőzött peripancreaticus folyadékgyülemek esetén percutan drainage és/vagy lavage történt. Amennyiben percutan drainage során gennyürülését észleltük, bakteriológiai vizsgálatra anyagot vettünk. Az üreget rendszeresen öblítettük, valamint a kezelést célzott antibiotikum kezeléssel egészítettük ki. A mütétet az ajánlásoknak megfelelően - amenynyiben azt a beteg állapota engedte - a betegség kezdetétől számított legalább 4-6. hétre terveztük. Ez az idő átlagosan $61,00 \pm 33,47$ nap volt.

A kialakult WOPN mütéti indikációt jelentett, ha fertőzött volt és konzervatív (antibiotikum) és/vagy szemikonzervatív (percutan drainage) kezelésre nem gyógyult, valamint méreténél fogva nyomási tüneteket vagy tartós szeptikus állapotot tartott fenn. Mütéti kezelés mellett döntöttünk nagy kiterjedésü (legalább $10 \mathrm{~cm}$ nagyságú), több rekeszből álló, illetve a retrocolicus és retroduodenális terekbe is terjedő necrosis esetén, mert ilyen esetekben a necrosis mérete, alakja és elhelyezkedése miatt a percutan öblítő drainage-tól gyógyulás nem volt várható.

Az operált demarkált necrosisok retrogastricus részének legnagyobb mérete átlagosan $14,00 \pm 5,23 \mathrm{~cm}$ volt, és valamennyi esetben a retrocolicus, retroduodenális terekbe is beterjedt. Az elváltozások fertőzött jellegét a percutandrain tartalmának bakteriológiai vizsgálata, valamint a CT morfológiai jelek (gázbuborékok) alapján igazoltuk (1. ábra).

A transgastricus mütétek során a gyomor mögött elhelyezkedő necrosist a gyomor elülső falának megnyitása után a hátsó falon ejtett kb. 6-7 cm-es metszésből távolítottuk el. A necrectomiát tompán, ujjal és water-jet technikával végeztük. A CT-képek alapján a gyomor hátsó falán keresztül megnyitott üregből feltártuk a lép, a bal rekesz alatti és a retrocolicus tereket, és innen is eltávolítottuk az elhalt

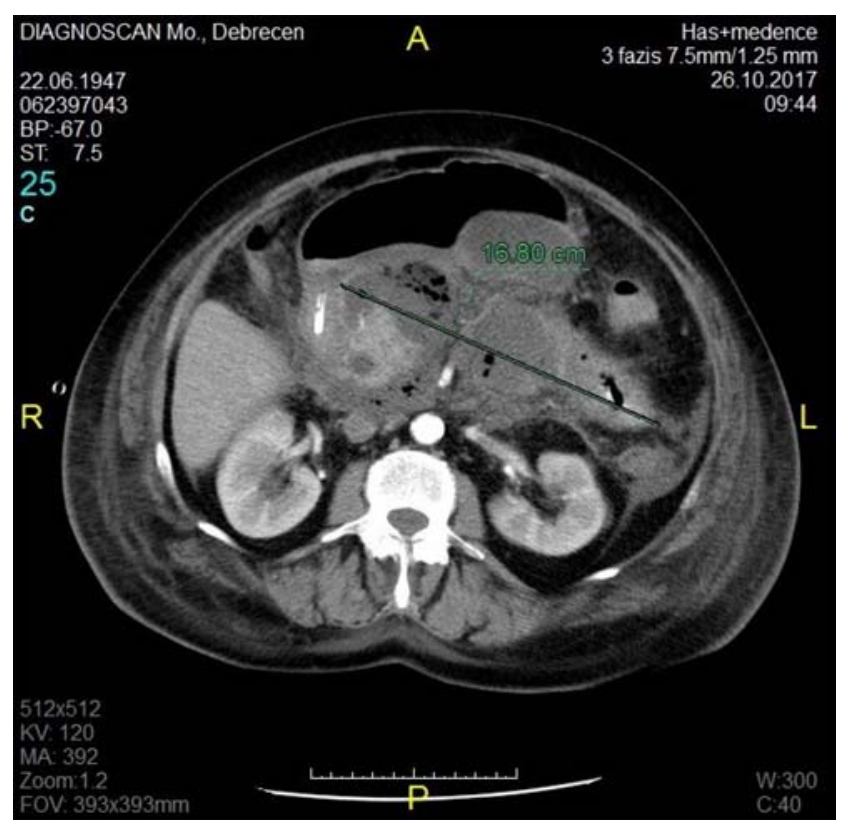

1. ábra. Demarkált pancreas necrosis CT-képe. A $16,8 \mathrm{~cm}$ legnagyobb átmérőjü elváltozásban levegőbuborékok láthatóak 


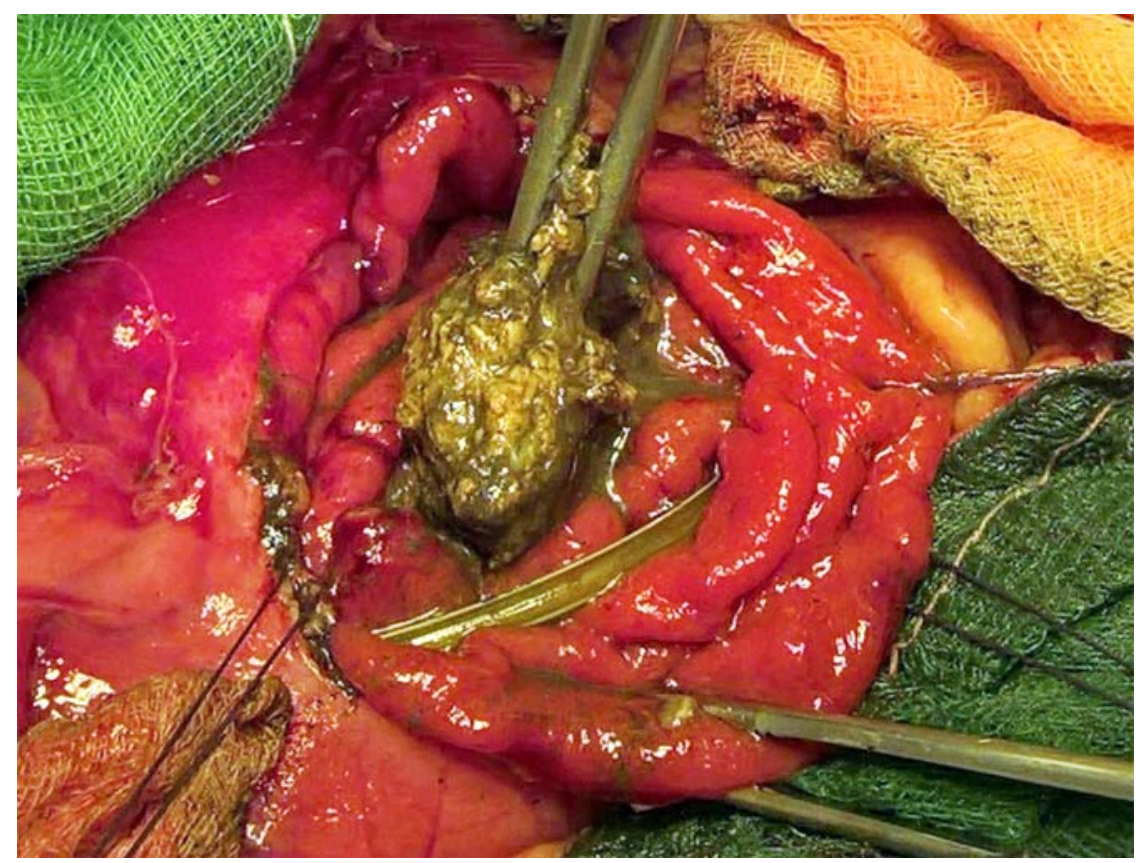

2. ábra. Nyitott sebészi, transgastricus necrectomia mütéti képe

szöveteket. A müveletet tompán ujjal és hosszú gyürüs epehólyagfogóval végeztük. Az üreget mindaddig mostuk, amíg további elhalt szövetek, illetve genny már nem ürült. A WOPN és a gyomor falát tovafutó varrattal egyesítettük a későbbi vérzések megelözése végett. A nasogastricusan levezetett szonda végét az üregbe helyeztük, a gyomor elülső falát tovafutó varrattal zártuk (2. ábra).

A szeptikus góc „megbolygatása” miatt valamennyi beteg 5 napos imipenemkezelésben részesült. A posztoperatív szakban négy betegnél a drain öblítését is végeztük. A betegek a mütét után nagy dózisban, naponta 3-4 alkalommal 50000 NE Pancreatinkezelésben részesültek.

Az adatok statisztikai értelmezésekor a Grubbs-teszt alkalmazása és Winsorizálás után a kiugró értékek 95\%-os percentilis adatokkal történő helyettesítése után számítottuk a median értékeket és a szórást (SD).

\section{Eredmények}

A transgastricus necrectomiával kapcsolatos intraoperatív szövődményt nem észleltünk. Egy esetben a WOPN a percutan drainage miatt nem volt tapintható, ezért a drainen keresztül steril fiziológiás sóoldattal feltöltöttük, és ezt követően végeztük el a gyomor hátsó falával a szájaztatást.

Korai posztoperatív szövődményt nem észleltünk, reoperáció nem történt. Sebgyógyulási zavart nem észleltünk. Egy betegnél a mütét után két héttel kialakult lázas állapot miatt két alkalommal endoszkópos lavage történt a WOPN és a gyomor közötti anastomosis elzáródása miatt (Clavien-Dindo Gr. IIIa). Ez a beteg a későbbiekben gyógyult. Egy másik betegnél a WOPN és a gyomor közötti szájadék szükülete miatt kellett tágítást végezni (ClavienDindo Gr. IIIa).
Egy beteget (5,9\%) veszítettünk el (Clavien-DindoGr.V). Az I-II. fokban elhízott (BMI: 35,6) 73 éves betegnél számos kísérőbetegség (hypertonia, pitvarfibrillatio, epilepsia, glaucoma, diabetes mellitus, valamint agyi lacunaris laesiók) súlyosbította az akut pancreatitist. A betegnél a mütéttel kapcsolatos szövődményt nem észleltünk, a halál oka veseelégtelenség, konzervatív kezeléssel befolyásolhatatlan metabolicus acidosis volt. A mütétek utáni kórházi tartózkodás átlagosan $10,00 \pm 3,08$ (8-57 nap) nap volt (1. táblázat).

A betegek átlagosan 27,00 $\pm 16,97$ (2-48 hónap) hónapos utánkövetés során jelentős súlygyarapodásról számoltak be. A konvencionális pancreas necrectomia után gyakran észlelhető pancreas sipoly és pseudocystaképződés egy esetben sem fordult elö.

A 16 túlélő beteg közül 2 betegnek volt 2-es típusú diabetes mellitusa, akik közül egynél a későbbiekben 1-es típusú diabetes mellitus alakult ki. Egy, a mütét előtt is már 1-es típusú diabetes mellitus miatt kezelt betegnél a diabetes nem súlyosbodott. Frissen kialakult diabetest egy esetben sem észleltünk. Összességében a meglévő cukorbetegség súlyosbodását az operált betegek közül 6,3\%-ban észleltük.

Az utánkövetés során egy betegnél hasfali hegsérv miatt, egy másik betegnél a később kialakult epekövesség miatt végeztünk mütétet.

\section{Megbeszélés}

Az akut pancreatitis súlyos eseteiben gyakran kényszerülünk intervenciós vagy sebészi beavatkozásokra. Kezelése alapvetően konzervatív és általánosan elfogadott elve a „stepup" kezelés. ${ }^{2,4,6,8,12-14,18,20}$ A pancreas necrosis eltávolítása általában csak olyan esetekben javasolt, ha az 
1. táblázat. A WOPN miatt kezelt betegek demográfiai adatai és kezelési eredményei

\begin{tabular}{lccccc}
\hline Nem & $\begin{array}{c}\text { Életkor } \\
(\text { év) }\end{array}$ & $\begin{array}{c}\text { A betegség kezdetétöl } \\
\text { eltelt idő (nap) }\end{array}$ & $\begin{array}{c}\text { A WOPN legnagyobb } \\
\text { átméröje }(\mathrm{cm})\end{array}$ & $\begin{array}{c}\text { Posztoperatív } \\
\text { szövödmény }\end{array}$ & Halálozás \\
\hline Nö & 66 & 35 & 9,5 & nem & nem \\
Férfi & 61 & 45 & 14 & nem & nem \\
Nö & 73 & 39 & 6 & nem & nem \\
Férfi & 48 & 62 & 6 & nem & nem \\
Férfi & 51 & 132 & 19,5 & nem & nem \\
Férfi & 56 & 46 & 15 & anastomosis elzáródása & nem \\
Férfi & 37 & 259 & 10 & endoszkópos lavage & nem \\
Férfi & 92 & 91 & 15 & nem & nem \\
Férfi & 45 & 61 & 16 & nem & nem \\
Nö & 74 & 61 & 10 & nem & nem \\
Nő & 64 & 61 & 11 & nem & nem \\
Férfi & 73 & 60 & 9 & nem & igen \\
Férfi & 34 & 41 & 12,5 & nem & nem \\
Férfi & 58 & 281 & 17 & anastomosis szükülete & nem \\
Férfi & 75 & 66 & 20 & endoszkópos tágítás & nem \\
Férfi & 70 & 52 & 25 & nem & nem \\
Nö & 70 & 21 & 18,5 & nem & nem \\
\hline WOPN: & & & & &
\end{tabular}

WOPN: Walled-off pancreatic necrosis

felülfertőződött és konzervatív vagy szemikonzervatív kezelésre nem gyógyul. A steril WOPN-t nem kell operálni, csak ha kompressziós vagy általános (láz, fogyás, étvágytalanság stb.) tüneteket okoz. ${ }^{1,3,5,6,8,10-14,16-19}$ A necrectomiát lehetőleg a betegség kezdetétől számított legalább 4-6. hétre kell tervezni, mert ekkor már többnyire kialakult az ún. demarkált necrosis. ${ }^{1-18}$

Ebben a stádiumban a kezelésre több lehetöség van. Kisebb, a gyomor és a duodenum mögött elhelyezkedő WOPN esetén a transgastricus endoszkópos necrectomia, a kettős malacfarok- (pig-tail) katéterezés és az ún. multiple transluminal gateway (többszörös kettős malacfarok-katéteres összeköttetés a gyomor és a WOPN között) alkalmazható. ${ }^{4,11-14,16-20}$ Emellett számos minimálisan invazív sebészi kezelési módszer (retroperitoneoscopy, sinus tractendoscopy stb.) ismeretes. . $^{3,4,12,14-16,18,20}$

Olyan necrosisok esetén, ahol méretüknél és elhelyezkedésüknél fogva az előbbi kezelésektől nem várható gyógyulás, a sebészi kezelés javasolt. A mütéti kezelés előnye továbbá a teljes necrectomia lehetősége és, hogy egy ülésben a kiváltó ok, az epekövesség kezelése is lehetséges. ${ }^{1-3,5-12,14-17,19}$ Rana és mtsai szerint a nyitott necrectomiák után 44\%-ban alakult ki friss diabetes mellitus. ${ }^{19}$ Ilyen magas arányú endokrin funkcióelégtelenséget (diabetes mellitus) más szerzők nem találtak..$^{2,8,16,17} \mathrm{~A}$ fentebb ismertetett betegeknél friss diabetes mellitus vagy a meglévő romlása csak 6,3\%-ban fordult elő.

A pancreas necrectomiának két alapvető típusa van. Az egyik a konvencionális necrectomia, melyet általában a bursaomentalis nyitott vagy zárt drainage-e követ. Ilyen mütétek után hosszabb ideig szükséges lehet a bursa öblítése, gyakran újabb necrectomia is indokolt lehet. ${ }^{3,4,6,8,12,14,19}$ Gyakran marad vissza hasnyálmirigy-sipoly, vagy később áltömlő alakulhat ki. ${ }^{3,4,8,12,14}$

A másik mütéti lehetőség a transgastricus necrectomia. Ez a módszer lényegében egy Jurasz-mütét, melynek alkalmával a WOPN és a gyomor között készített nyíláson át történik meg a necrectomia. ${ }^{1,2,5-8,10-12,14-16}$ A mütét alkalmával behelyezett „naso-cysticus” szondán keresztül, mint a szerzők anyagában, 4 esetben a posztoperatív öblítés is lehetséges. 2,12,16 Ilyen mütétek különböző laparoszkópos technikával is jó eredménnyel végezhetők. 1,5,8,9,11,12,14-17

A mütét további előnye, hogy nincs a hasfalon keresztüli drainage, és a mütét jellegénél fogva nem alakulhat ki pancreas sipoly és pseudocysta. ${ }^{1,2,5-12,14-17}$ A szerzők 17 betegnél egy esetben sem tapasztaltak pancreas sipoly- és pseudocystaképződést. A mütét utáni ápolási napok száma alacsony 5-15,5 nap. ${ }^{1,2,5-9,11,16,17}$ A szerzők által ismertetett betegeknél ez átlagosan 11,6 nap volt. A transgastricus necrectomiák utáni szövődmények ritkák, a mortalitás alacsony és általában nem a mütéttel kapcsolatos. ${ }^{1,2,5-8,10,12,16,17}$

Összefoglalva, a szerzők saját és mások kedvező tapasztalatai alapján úgy gondolják, hogy a demarkált pancreas necrosis sebészi kezelésében a transgastricus módszer javasolható azokban az esetekben, amikor a WOPN nagy kierjedésü és egy jelentős része a gyomor mögött helyezkedik el. A mütét előnye, hogy a necrectomia után nem alakulhat ki hasnyálmirigy-sipoly és pseudocysta. 
Nyilatkozat: A közlemény más folyóiratban korábban nem jelent meg, és máshova beküldésre nem került. A cikk végleges változatát valamennyi szerző elolvasta és jóváhagyta. Szerzői munkamegosztás: Valamennyi szerző (Balog Klaudia, Csiszkó Adrienn, Krasnyánszky Nóra, Farkas Máté, Berhés Mariann, László István, Palatka Károly, Damjanovich László, Sápy Péter, Szentkereszty Zsolt) részt vett a közlemény adatgyüjtésében és a cikk szerkesztésében. Anyagi támogatás: A közlemény megírása, illetve a kapcsolódó kutatómunka anyagi támogatásban nem részesült. Érdekeltségek: A szerző(k)nek a közlemény megírásában, megjelenésében nincsenek érdekeltségei(k).

\section{Irodalomjegyzék}

${ }^{1}$ Worhunsky DJ, Qadan M, Dua MM, et al. Laparoscopic transgastric necrosectomy for the management of pancreatic necrosis. J Am Coll Surg. 2014 Oct; 219(4): 735-743.

${ }^{2}$ Gerin O, Prevot F, Dhahri A, et al. Laparoscopy-assisted open cystogastrostomy and pancreatic debridement for necrotizing pancreatitis (with video). Surg Endosc. 2016 Mar; 30(3): 1235-1241.

${ }^{3}$ Vasiliadis K, Papavasiliou C, Al Nimer A, et al. The role of open necrosectomy in the current management of acute necrotizing pancreatitis: a review article. ISRN Surg. 2013 ID 579435, http://dx.doi. org/10.1155/2013/579435.

${ }^{4}$ Bakker OJ, van Santvoort HC, van Brunschot $S$, et al. Endoscopic transgastric vs surgical necrosectomy for infected necrotizing pancreatitis: a randomized trial. JAMA. 2012 Mar 14; 307(10): 1053-1061.

${ }^{5}$ Kulkarni S, Bogart A, Buxbaum J, et al. Surgical transgastric debridement of walled-off pancreatic necrosis: an option for patients with necrotizing pancreatitis. Surg Endosc. 2015 Mar; 29(3): 575-582.

${ }^{6}$ Munene G, Dixon E, Sutherland F. Open transgastric debridement and internal drainage of symptomatic non-infected walled-off pancreatic necrosis. HPB (Oxford). 2011 Apr; 13(4): 234-239.

7 Sasnur P, Nidoni R, Baloorkar R, et al. Extended Open Transgastric Necrosectomy (EOTN) as a safer procedure for necrotizing pancreatitis. J Clin Diagn Res. 2014 Jul; 8(7): NR01-2. DOI: 10.7860/JCDR/2013/8196.4600.

${ }^{8}$ Mathew MJ, Parmar AK, Sahu D, et al. Laparoscopic necrosectomy in acute necrotizing pancreatitis: Our experience. J Minim Access Surg. 2014 Jul; 10(3): 126131.

${ }^{9}$ Simo KA, Niemeyer DJ, Swan RZ, et al. Laparoscopic transgastric endolumenal cystogastrostomy and pan- creatic debridement. Surg Endosc. 2014 May; 28(5): 1465-1472.

${ }^{10}$ Busse MJ, Ainsworth AP. Ten years of experience with transgastric necrosectomy for walled-off necrosis in acute pancreatitis. Dan Med J. 2015 Sept; 62(9): 1-4.

11 Gibson SC, Robertson BF, Dickson EJ, et al. 'Step-port' laparoscopic cystgastrostomy for the management of organized solid predominant post-acute fluid collections after severe acute pancreatitis. HPB (Oxford). 2014 Feb; 16(2): 170-176.

12 Szentkereszty Z, Balog K, Balázs L, et al. The treatment of walled-off pancreatic necrosis. Review. [A demarkált pancreasnecrosis sebészi kezelése. Irodalmi áttekintés] Orv Hetil. 2016 Nov; 157(47): 1866-1870. [Hungarian]

${ }^{13}$ Hritz I, Czakó L, Dubravcsik Z, et al. Acute pancreatitis. Evidence-based practice guidelines, prepared by the Hungarian Pancreatic Study Group. [Magyar Hasnyálmirigy Munkacsoport, Hungarian Pancreatic Study Group: Akut pancreatitis. A Magyar Hasnyálmirigy Munkacsoport bizonyítékon alapuló kezelési irányelvei.] Orv Hetil. 2015 Feb 15; 156(7): 244-261. [Hungarian]

14 Szentkereszty Zs. Principles and changes in the surgical treatment of acute pancreatitis. [A súlyos akut pancreatitisek sebészi kezelési elvei, azok alakulása.] Centr Eur J Gastroenterol Hepatol. 2016 March; 2(1): 4-7. [Hungarian]

15 Zyromski NJ, Nakeeb A, House MG, et al. Transgastric pancreatic necrectomy: How I do it. J Gastrointest Surg. 2016 Feb; 20(2): 445-449.

${ }^{16}$ Dua MM, Worhunsky DJ, Malhotra L, et al. Transgastric pancreatic necrosectomy-expetited return to prepancreatitis health. J Surg Res. 2017 Nov; 219: 11-17.

17 Worhunsky DJ, Qadan M, Dua MM, et al. Laparoscopic transgastric necrosectomy for the management of pancreatic necrosis. J Am Coll Surg. 2014 Oct; 219(4): 735-743.

18 van Brunschot S, van Grinsven J, van Santvoort HC, et al. Endoscopic or surgical step-up approach for infected necrotising pancreatitis: a multicentre randomised trial. Lancet. 2017 Nov 3. pii: S0140-6736(17)32404-2. DOI: $10.1016 / \mathrm{S} 0140-6736(17) 32404-2$.

${ }^{19}$ Rana SS, Bhasin DK, Rao C, et al. Comparative evaluation of structural and functional changes in pancreas after endoscopic and surgical management of pancreatic necrosis. Ann Gastroenterol. 2014; 27(2): 162-166.

${ }^{20}$ Rasch S, Phillip V, Reichel S, et al. Open surgical versus minimal invasive necrosectomy of the pancreas A retrospective multicenter analysis of the German Pancreatitis Study Group. PLoSOne. 2016 Sep 26; 11(9): e0163651. DOI: 10.1371/journal.pone.0163651.

A cikk a Creative Commons Attribution 4.0 International License (https://creativecommons.org/licenses/by/4.0/) feltételei szerint publikált Open Access közlemény, melynek szellemében a cikk bármilyen médiumban szabadon felhasználható, megosztható és újraközöl= hetö, feltéve, hogy az eredeti szerző és a közlés helye, illetve a CC License linkje és az esetlegesen végrehajtott módosítások feltüntetésre kerülnek. (SID_1) 